\title{
Heat effects in the reaction of sulfuric acid with ilmenites influenced by initial temperature and acid concentration
}

\author{
Maciej Jabłoński ${ }^{1}$, Krzysztof Lubkowski1 ${ }^{1,}$, Sandra Tylutka ${ }^{1}$, Andrzej Ściążko ${ }^{2}$ \\ ${ }^{1}$ West Pomeranian University of Technology Szczecin, Faculty of Chemical Technology and Engineering, Department \\ of Organic and Physical Chemistry, Al. Piastów 42, 71-065 Szczecin, Poland \\ ${ }^{2}$ Grupa Azoty Zakłady Chemiczne "Police” S.A., Kuźnicka 1, 72-010 Police \\ "Corresponding author: e-mail: Krzysztof.Lubkowski@zut.edu.pl
}

\begin{abstract}
The influence of temperature and sulfuric acid concentration on the enthalpy and the rate of heat release during the reaction of Norwegian and Australian ilmenites with sulfuric acid was determined. The experimental results obtained from calorimetric measurements were compared with theoretical calculations based on the oxide composition and the phase composition of the raw material. Experimentally determined heat of reaction for Norwegian ilmenite $(900-940 \mathrm{~kJ} / \mathrm{kg}$ ) and Australian ilmenite $(800-840 \mathrm{~kJ} / \mathrm{kg}$ ) showed good agreement with theoretical calculations based on the phase composition of the raw material. It was found that the enthalpy of ilmenites decomposition reaction does not depend on the concentration of sulfuric acid in the concentration range from $83 \%$ to $93 \%$. It was also demonstrated that the temperature and concentration of sulfuric acid have a significant impact on the thermokinetics of the decomposition process, increasing the value of the average rate of temperature change.
\end{abstract}

Keywords: ilmenites digestion, sulfuric acid, enthalpy of reaction.

\section{INTRODUCTION}

The reaction of titanium-bearing minerals with sulfuric acid is of great practical and technological importance, as it is the first stage in the production of titanium dioxide pigments by the sulfate method ${ }^{1-4}$. Recently, attention has been paid to the importance of this technology, both in the context of using the flotation process in the extraction and preparation of raw materials ${ }^{5,6}$, as well as the mechanism and thermodynamics of raw materials decomposition ${ }^{7}$ and mechanical, thermal and chemical activation of raw materials ${ }^{8}$.

In the sulfate process, ilmenite ores (mostly $\mathrm{FeTiO}_{3}$ with $\mathrm{TiO}_{2}$ content of $43-65 \%$ ) and/or titaniferous slags (metallurgy-enriched ilmenite ores with $\mathrm{TiO}_{2}$ content of $70-80 \%$ ) are digested with highly concentrated sulfuric acid $(80-95 \%)$ to produce liquor containing mainly titanyl and iron sulfates. The reaction is strongly exothermic, accompanied with a significant emission of gases, takes place in highly corrosive environment at a high temperature and runs the risk of real thermal explosion as a result of uncontrolled rate of reaction' ${ }^{9}$. The reactions with a risk of uncontrolled run, leading to thermal runaway, are called the hazard-type reactions $\mathbf{s}^{\mathbf{1 0}, 11}$. One of the methods used to determine the safety of hazard-type reactions is the study of changes in thermal power during the process (thermokinetics), using reaction calorimeters of different types ${ }^{12-17}$. The thermal effect and thermokinetics of the sulfuric acid reaction with titanium raw materials strongly depend on such parameters as the initial concentration of sulfuric acid ${ }^{18}$, reaction initiation temperature ${ }^{19}$ and the particle size of the titanium raw material ${ }^{20}$. The impact of these parameters on the course of the reaction is also dependent on the elemental and phase composition of titanium raw materials ${ }^{21}$. Because of a large variety of titanium-bearing minerals, the results of the reaction thermokinetics refer only to a given type of raw material. Knowledge of the impact of initial parameters on the thermal effects of the reaction is of key importance for the safety of the technological process because excessive emission of heat generated during the reaction risks the danger of explosion, ${ }^{92}$. On the other hand, improper selection of the initial reaction parameters may also lead to incomplete reaction of the reaction mixture, which in turn contributes to specific and measurable economic losses.

The thermal effect of the reaction and its thermokinetics are closely related. The reaction rate is a function of temperature. The greater the amount of heat evolved during the reaction (thermal effect of the reaction), the higher the temperature of the reaction mixture and thus the faster the reaction rate. Knowledge of the thermal effect of the reaction is very important because it allows assessment of the reaction kinetics and thus corrects choice of its optimal initial conditions. From the technological point of view and taking into account the process safety, it is extremely important to accurately analyze and specify the total thermal effect and thermokinetics of the decomposition reaction as well as the influence of sulfuric acid concentration. Therefore, this study was aimed to exactly determine the effect of the initial sulfuric acid concentration on the total amount of heat released during the reaction of sulfuric acid with titanium raw materials as well as on the rate of heat release in this process. The purpose of this research was also to determine the influence of temperature on the thermal effects of the raw materials decomposition reaction in correlation with precise theoretical calculations. Such an approach to issues related to the technology of processing titanium-bearing raw materials has not been presented in the available literature so far.

\section{EXPERIMENTAL}

\section{Methods}

The heat of the reaction of ilmenites with sulfuric acid can be determined by experimental methods using reaction calorimeters. The results obtained from the calorimetric measurement allow estimation of the degree of raw material conversion with time, based on the amount of heat generated during the reaction. Norwegian 
and Australian ilmenites, differing significantly in both elemental and phase composition, were used in the study. On the basis of the X-ray fluorescence analysis and thermogravimetric measurements, the following elemental compositions were obtained (expressed as oxides): $\mathrm{TiO}_{2}$ $-44.4 \%, \mathrm{FeO}-34.8 \%, \mathrm{Fe}_{2} \mathrm{O}_{3}-11.6 \%, \mathrm{MgO}-4.1 \%$ for Norwegian ilmenite ${ }^{20}$, and $\mathrm{TiO}_{2}-55.1 \%, \mathrm{FeO}-20.8 \%$, $\mathrm{Fe}_{2} \mathrm{O}_{3}-19.6 \%, \mathrm{MgO}-0.3 \%, \mathrm{MnO}-1.8 \%$ for Australian ilmenite $^{21}$. X-ray absorption, diffraction and fluorescence measurements ${ }^{21}$ have shown that the main phases in Norwegian ilmenite ores are: ilmenite $\mathrm{FeTiO}_{3}-74.5 \%$, hematite $\mathrm{Fe}_{2} \mathrm{O}_{3}-11.6 \%$ and geikielite $\mathrm{MgTiO}_{3}-7.9 \%$. In addition, a probable presence of enstatite $\mathrm{MgSiO}_{3}$ $4.3 \%$ and less than $1 \%$ of $\mathrm{MnTiO}_{3}$ was established. In Australian ilmenite ores, the main phases are: ilmenite $\mathrm{FeTiO}_{3}-44.0 \%$, pseudorutile $\mathrm{Fe}_{2} \mathrm{Ti}_{3} \mathrm{O}_{9}-44.0 \%$, hematite $\mathrm{Fe}_{2} \mathrm{O}_{3}-2 \%$. In addition, a probable presence of kleberite $\mathrm{FeTi}_{3} \mathrm{O}_{6}(\mathrm{OH})_{3}-4 \%, \mathrm{MnTiO}_{3}-3 \%$ and geikielite $\mathrm{MgTiO}_{3}-1 \%$ was also indicated.

Due to the specific reaction conditions (high temperature during the reaction, the fact that heat released increases the temperature of the reaction mixture to 190 $220{ }^{\circ} \mathrm{C}$, depending on the type of titanium raw material, highly corrosive environment, possible gas emission and risk of thermal explosion), in calorimetric measurements a non-isothermal and non-adiabatic calorimeter of our construction was used. The calorimeter was equipped with a calorimeter vessel with a capacity of $0.6 \mathrm{dm}^{3}$, in which an electric heater, stirrer, temperature sensor, dispenser and safety valve were placed. The calorimetric vessel parameters were as follows: time constant - 257.5 min, heat transfer coefficient $-0.098 \mathrm{~J} \cdot \mathrm{K}^{-1} \cdot \mathrm{s}^{-1}$. The mass of ilmenite sample used in the study was about $100 \mathrm{~g}$, while the mass of sulfuric acid was in the range from $200 \mathrm{~g}$ to $400 \mathrm{~g}$, depending on the concentration of the acid. The reaction was initiated by introducing ilmenite into sulfuric acid at a given temperature. The reaction time depended on the process conditions used and ranged from 70 to 100 minutes.

As a result of the calorimetric measurements, the dependencies $\mathrm{T}=\mathrm{f}_{1}(\mathrm{t})$, dT/dt $=\mathrm{f}_{2}(\mathrm{t})$ and $\mathrm{W}=\mathrm{dQ} / \mathrm{dt}=\mathrm{f}_{3}(\mathrm{t})$ have been obtained (with the symbols having the usual meaning). Integrating the expression $\left(\frac{d T}{d t}\right)_{a v}=\frac{1}{t} \int_{0}^{t} f_{2}(t) d t$ for the time $\mathrm{t}$, at which $\mathrm{W}(\mathrm{t})=0$, the average rate of temperature change during the reaction has been obtained, whereas integrating the expression $Q_{r}=\int_{0}^{t} f_{3}(t) d t$ the thermal effect of the reaction has been obtained.

During the investigated process, the heat of ilmenite wetting with sulfuric acid should also be considered. Based on earlier studies ${ }^{\mathbf{2 3}}$, it was found that the average value of heat of titanium-bearing minerals wetting with sulfuric acid is from $4 \mathrm{~kJ} / \mathrm{kg}$ to $10 \mathrm{~kJ} / \mathrm{kg}$, and the total error related to the measurement of the heat of wetting and the amount of thermal effects associated with the reactions of accompanying compounds is about $1 \%$.

\section{RESULTS AND DISCUSSION}

In the interpretation of the experimental results, theoretical calculations of the thermal effects have been used. In the reaction of sulfuric acid with titanium raw materials, the amount of heat released depends on the elemental and phase composition of the titanium raw material and the concentration of sulfuric acid. The enthalpy effect of the reaction has been calculated based on thermodynamic data (enthalpy of formation) for all components of the reaction mixture, taking into account a) the oxide composition, and b) the phase composition of the raw material.

\section{Calculations based on the oxide composition of the raw material}

It has been shown ${ }^{\mathbf{1 8}}$ that the degree of conversion (leaching - transition to the solution phase) of $\mathrm{TiO}_{2}$, $\mathrm{FeO}$ and $\mathrm{Fe}_{2} \mathrm{O}_{3}$ is similar for both titanium and iron. Because in the studied ilmenites titanium and iron are dominant elements (the remaining elements are present in a small amount of about 1-2\%), it can be assumed that the heat generated during the process is the result of the following reactions:

$\mathrm{TiO}_{2}+\mathrm{H}_{2} \mathrm{SO}_{4} \rightarrow \mathrm{TiOSO}_{4}+\mathrm{H}_{2} \mathrm{O}$
$\mathrm{FeO}+\mathrm{H}_{2} \mathrm{SO}_{4} \rightarrow \mathrm{FeSO}_{4}+\mathrm{H}_{2} \mathrm{O}$
$\mathrm{Fe}_{2} \mathrm{O}_{3}+3 \mathrm{H}_{2} \mathrm{SO}_{4} \rightarrow \mathrm{Fe}_{2}\left(\mathrm{SO}_{4}\right)_{3}+3 \mathrm{H}_{2} \mathrm{O}$
$\mathrm{MgO}+\mathrm{H}_{2} \mathrm{SO}_{4} \rightarrow \mathrm{MgSO}_{4}+\mathrm{H}_{2} \mathrm{O}$

For Australian ilmenite, the following reaction should also be considered:

$\mathrm{MnO}+\mathrm{H}_{2} \mathrm{SO}_{4} \rightarrow \mathrm{MnSO}_{4}+\mathrm{H}_{2} \mathrm{O}$

Based on our unpublished research and other works ${ }^{7}$ it was found that rutile is highly resistant to sulfuric acid, thus only thermodynamic data for anatase have been used in the calculations. In the case of the reaction taking place under the presented conditions, mainly $\mathrm{TiOSO}_{4}$ is formed, which is confirmed by calorimetric measurements and the results presented in the referenced paper $^{24}$. However, the formation of other compounds in this reaction (for example $\left.\mathrm{Ti}\left(\mathrm{SO}_{4}\right)_{2}\right)$ should not be excluded ${ }^{7}$.

To calculate the thermal effect of the reaction of titanium raw materials with sulfuric acid, the available thermodynamic data on the enthalpy of formation of individual compounds present in the reaction mixture were used ${ }^{25-28}$ and the calculated enthalpies of individual reactions are presented in Table 1.

Table 1. Enthalpies of reactions calculated on the basis of thermodynamic data

\begin{tabular}{|l|c|}
\hline Reaction & $\begin{array}{c}\text { Enthalpy } \\
(\mathrm{kJ} / \mathrm{mol})\end{array}$ \\
\hline $\mathrm{TiO}_{2}+\mathrm{H}_{2} \mathrm{SO}_{4} \rightarrow \mathrm{TiOSO}_{4}+\mathrm{H}_{2} \mathrm{O}$ & -27.6 \\
\hline $\mathrm{FeO}+\mathrm{H}_{2} \mathrm{SO}_{4} \rightarrow \mathrm{FeSO}_{4}+\mathrm{H}_{2} \mathrm{O}$ & -128.2 \\
\hline $\mathrm{Fe}_{2} \mathrm{O}_{3}+3 \mathrm{H}_{2} \mathrm{SO}_{4} \rightarrow \mathrm{Fe}_{2}\left(\mathrm{SO}_{4}\right)_{3}+3 \mathrm{H}_{2} \mathrm{O}$ & -172.8 \\
\hline $\mathrm{MgO}+\mathrm{H}_{2} \mathrm{SO}_{4} \rightarrow \mathrm{MgSO}_{4}+\mathrm{H}_{2} \mathrm{O}$ & -158.8 \\
\hline $\mathrm{MnO}+\mathrm{H}_{2} \mathrm{SO}_{4} \rightarrow \mathrm{MnSO}_{4}+\mathrm{H}_{2} \mathrm{O}$ & -151.9 \\
\hline
\end{tabular}

Due to differences in the enthalpies of formation of some compounds (especially magnesium compounds) available in the literature, the reaction enthalpy may be charged with up to $10 \%$ error. Taking into account the elemental composition of both raw materials, the calculated enthalpy of the reaction with sulfuric acid at 298.15 $\mathrm{K}$ is $-994.1 \mathrm{~kJ} / \mathrm{kg}$ (of the raw material) for Norwegian ilmenite and $-822.2 \mathrm{~kJ} / \mathrm{kg}$ for Australian ilmenite. In the calculations, $100 \%$ conversion of titanium oxides and iron oxides was assumed. In the case of magnesium oxide the conversion of about $63 \%$ was assumed because a part of this component content is in the form of magnesium silicate $\mathrm{MgSiO}_{3}$, which in the process conditions does 
not react with sulfuric acid ${ }^{24}$. The enthalpy of reaction obtained in this way is an approximate value, since in the actual reaction mixture more complicated processes may occur (e.g. indirect reactions).

\section{Calculations on the basis of the phase composition of the raw material}

Similar calculations of the enthalpy of reactions can be made taking into account the phase composition of raw materials, and assuming that, in addition to the reaction of hematite with sulfuric acid (reaction 3), the following reactions take place:

$$
\begin{aligned}
& \mathrm{FeTiO}_{3}+2 \mathrm{H}_{2} \mathrm{SO}_{4} \rightarrow \mathrm{FeSO}_{4}+\mathrm{TiOSO}_{4}+2 \mathrm{H}_{2} \mathrm{O} \\
& \mathrm{MgTiO}_{3}+2 \mathrm{H}_{2} \mathrm{SO}_{4} \rightarrow \mathrm{MgSO}_{4}+\mathrm{TiOSO}_{4}+2 \mathrm{H}_{2} \mathrm{O} \\
& 2 \mathrm{Fe}(\mathrm{OH})_{3}+3 \mathrm{H}_{2} \mathrm{SO}_{4} \rightarrow \mathrm{Fe}_{2}\left(\mathrm{SO}_{4}\right)_{3}+6 \mathrm{H}_{2} \mathrm{O}
\end{aligned}
$$

Due to the lack of thermodynamic data for $\mathrm{Fe}_{2} \mathrm{Ti}_{3} \mathrm{O}_{9}$ and $\mathrm{FeTi}_{3} \mathrm{O}_{6}(\mathrm{OH})_{3}$, these phases were treated as mixtures of appropriate compounds: $\mathrm{Fe}_{2} \mathrm{O}_{3} \cdot 3 \mathrm{TiO}_{2}$ and $\mathrm{Fe}(\mathrm{OH})_{3} \cdot 3 \mathrm{TiO}_{2}$ in the case of pseudorutile and kleberite, respectively. Using the thermodynamic data available in literature ${ }^{25-28}$, the enthalpies of the above reactions were calculated to be $-131.7 \mathrm{~kJ} / \mathrm{mol}$ for reaction $(6),-151.9 \mathrm{~kJ} /$ mol for reaction (7) and $-208.7 \mathrm{~kJ} / \mathrm{mol}$ for reaction (8). The value of $1495 \mathrm{~kJ} / \mathrm{mol}$ was assumed as the enthalpy of titanyl sulfate $\mathrm{TiOSO}_{4}$ formation ${ }^{25}$. Literature also provides the value of enthalpy of titanyl sulfate $\mathrm{TiOSO}_{4}$ formation as $1870 \mathrm{~kJ} / \mathrm{mol}^{29}$. However, inclusion of this value in theoretical calculations gives the enthalpies of decomposition reactions far different from the experimental values obtained for Norwegian and Australian ilmenite. The enthalpy of the reaction of Norwegian and Australian ilmenite with sulfuric acid at $298.15 \mathrm{~K}$, calculated based on the phase composition of the raw material is $-871.0 \mathrm{~kJ} / \mathrm{kg}$ and $-746.8 \mathrm{~kJ} / \mathrm{kg}$, respectively.

The difference in the enthalpy of the reaction determined by the two methods (calculations based on the oxide composition and the phase composition of the raw material) is quite significant $(-994.1 \mathrm{~kJ} / \mathrm{kg}$ and $-871.0 \mathrm{~kJ} / \mathrm{kg}$ for Norwegian ilmenite and $-822.2 \mathrm{~kJ} / \mathrm{kg}$ and $-746.8 \mathrm{~kJ} / \mathrm{kg}$ for Australian ilmenite). It should be noted, however, that the enthalpies of oxide formation are different from the enthalpies of formation of the compound identified by the phase analysis. And this very difference is reflected in the obtained reaction enthalpies.

The results of calculations of the enthalpy of the above reactions refer to a temperature of $298.15 \mathrm{~K}$, while the first thermal effects of sulfuric acid reaction with Norwegian and Australian ilmenites are visible above $323 \mathrm{~K}$ and $333 \mathrm{~K}$, respectively. Therefore, based on the available thermodynamic data ${ }^{25-28}$, theoretical calculations of the enthalpy of the reaction were carried out in the temperature range from $333 \mathrm{~K}$ to $363 \mathrm{~K}$ for Norwegian ilmenite and from $353 \mathrm{~K}$ to $383 \mathrm{~K}$ for Australian ilmenite. The results of these calculations are presented in Fig. 1 and Fig. 2 for Norwegian and Australian ilmenites, respectively.

Due to the significant impact of temperature on the progress of ilmenite decomposition reaction, it is important to choose the optimal reaction temperature so that the process would not run too slowly (unsatisfactory conversion) or too fast, which could bring thermal explosion. To determine the influence of temperature on the reaction heat, the experiments were carried out at the following reaction initiation temperatures: $333 \mathrm{~K}$ for Norwegian ilmenite and $353 \mathrm{~K}$ for Australian ilmenite. The evaluated experimental data - the thermal effects (reaction heat values) of the reaction of both ilmenites with sulfuric acid of $84 \%$ at four different temperatures from the aforementioned temperature ranges are also shown in Fig. 1 and Fig. 2.

As follows from these data, in the analyzed temperature range the changes in the heat of reaction are not significant and are from $900 \mathrm{~kJ} / \mathrm{kg}$ to $940 \mathrm{~kJ} / \mathrm{kg}$ for Norwegian ilmenite (Fig. 1) and from $800 \mathrm{~kJ} / \mathrm{kg}$ to 840 $\mathrm{kJ} / \mathrm{kg}$ for Australian ilmenite (Fig. 2). In addition to the experimental results, Fig. 1 and Fig. 2 also present the values of reaction enthalpy calculated theoretically. Lines (a) on both Figures correspond to the enthalpy of the reaction calculated based on the oxide composition of the raw material. The calculated enthalpy of the reaction significantly exceeds the values obtained experimentally, even taking into account the error resulting from different values of enthalpy of formation given in the literature $( \pm 27.7 \mathrm{~kJ} / \mathrm{kg})$.

Lines (b) on both Figures present the results of calculations of the enthalpy of the reaction obtained based on the phase composition of the raw material. Taking into account the calculation error resulting from different values of enthalpy of formation given in the literature, and the error of experiments marked on the graph, a satisfactory agreement of results was obtained in this case.

The effect of temperature on the enthalpy of the reaction is not great, since the heat capacity of the reactants and products is weakly temperature-dependent, except for water and sulfuric acid. As follows from analysis of the reaction enthalpy values calculated for analyzed temperatures, the reaction enthalpy both for Norwegian and Australian ilmenites in this temperature range varies within $5 \%$, which is confirmed by the experimental results presented in Fig. 1 and Fig. 2.

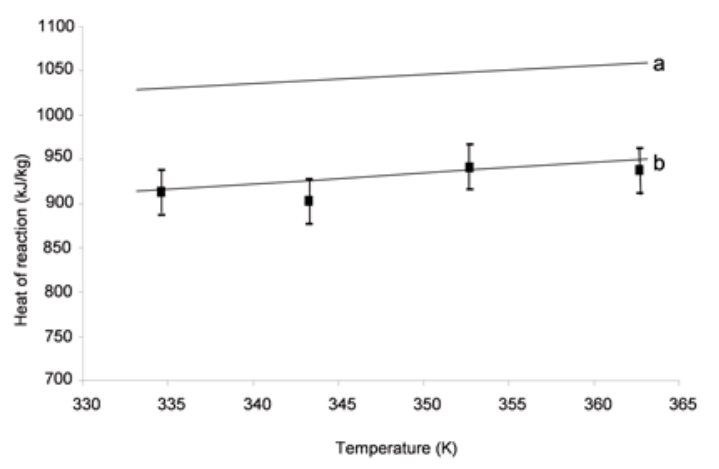

Figure 1. The experimental heat of reaction of sulfuric acid with Norwegian ilmenite depending on the reaction initiation temperature (markers on the chart) in comparison with (a) reaction enthalpy calculated based on the oxide composition of the raw material, (b) reaction enthalpy calculated based on the phase composition of the raw material

Fig. 3 and Fig. 4 show the relationship between the average rate of temperature changes $(\mathrm{dT} / \mathrm{dt})_{\mathrm{av}}$ and the temperature at which the reaction was initiated for Norwegian and Australian ilmenites, respectively. The 


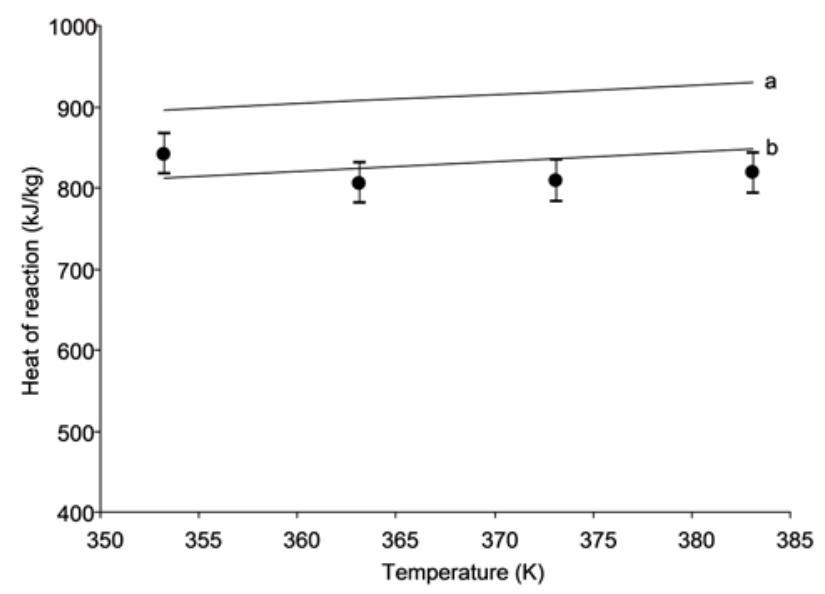

Figure 2. The experimental heat of reaction of sulfuric acid with Australian ilmenite depending on the reaction initiation temperature (markers on the chart) in comparison with (a) reaction enthalpy calculated based on the oxide composition of the raw material, (b) reaction enthalpy calculated based on the phase composition of the raw material

average rate of temperature changes is a very important thermokinetic parameter of the process. Analysis of the presented results suggests that the temperature of the reaction mixture substantially affects the kinetics of the reaction. The practically linear relationship between the average value of $(\mathrm{dT} / \mathrm{dt})_{\mathrm{av}}$ indicates the significant slowdown of the reaction below $333 \mathrm{~K}$ for Norwegian ilmenite and below $353 \mathrm{~K}$ for Australian ilmenite. It can be also seen that the temperature has a greater influence on the thermokinetics of Australian ilmenite decomposition. The initiation temperature of Australian ilmenite decomposition is indeed higher than that of Norwegian ilmenite, but the change of $(\mathrm{dT} / \mathrm{dt})_{\mathrm{av}}$ is significantly greater in the case of Australian ilmenite $(\sim 2 \mathrm{~K} / \mathrm{min})$ in the temperature range $353-383 \mathrm{~K}$ than in the case of Norwegian ilmenite $(\sim 1.4 \mathrm{~K} / \mathrm{min})$ in the temperature range 333-363 K.

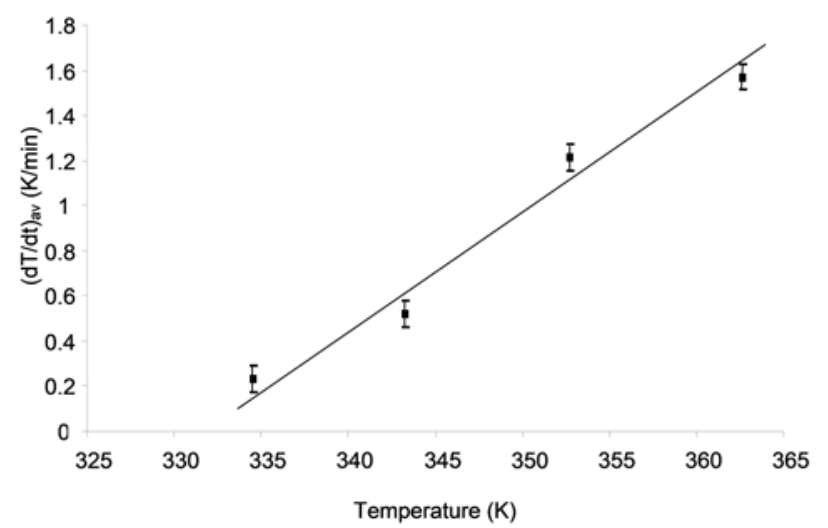

Figure 3. The dependence of the average rate of temperature change on the temperature of reaction initiation for Norwegian ilmenite

Fig. 5 and Fig. 6 present the dependence of the experimentally determined heat of reaction of Norwegian and Australian ilmenites with sulfuric acid on the initial acid concentration. The lines corresponding to the enthalpy of reaction calculated based on the oxide composition of the raw material (line a) and reaction enthalpy calculated based on the phase composition of the raw

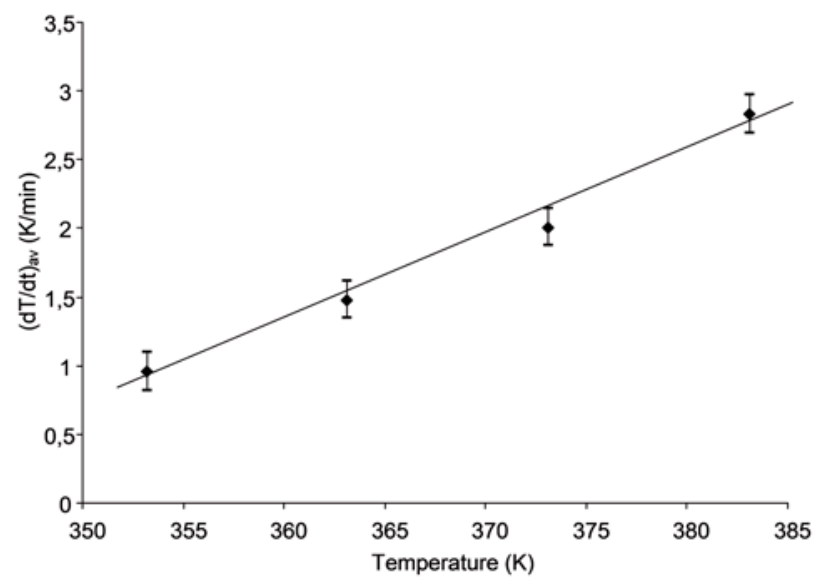

Figure 4. The dependence of the average rate of temperature change on the temperature of reaction initiation for Australian ilmenite

material (line b) are also plotted on both graphs. The calculated values of reaction enthalpy are $1048.4 \mathrm{~kJ} / \mathrm{kg}$ (line a) and $938.1 \mathrm{~kJ} / \mathrm{kg}$ (line b) for Norwegian ilmenite and $906.9 \mathrm{~kJ} / \mathrm{kg}$ (line a) and $824.4 \mathrm{~kJ} / \mathrm{kg}$ (line b) for Australian ilmenite. On both Figures, the most of the experimental points fall between the theoretical lines. The average heat of reaction in the investigated range of sulfuric acid concentrations is $977.4 \mathrm{~kJ} / \mathrm{kg}$ and $844.6 \mathrm{~kJ} /$ $\mathrm{kg}$ for Norwegian and Australian ilmenites, respectively. Both values are more similar to the heat of the reaction calculated theoretically based on the oxide composition of the raw material. Taking into account the measurement error of about $2 \%$, it can be concluded that the heat of ilmenites decomposition reaction does not depend on the initial concentration of sulfuric acid in the concentration range from $83 \%$ to $93 \%$.

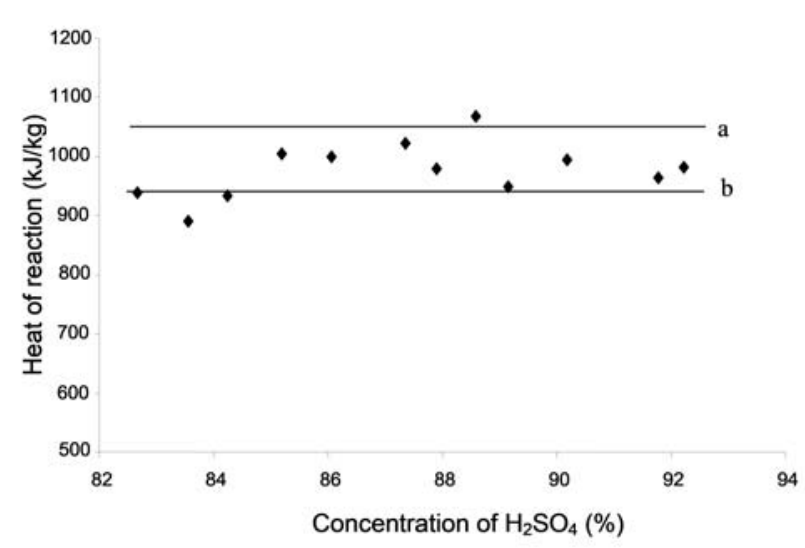

Figure 5. Dependence of the heat of reaction of Norwegian ilmenite with sulfuric acid on the initial acid concentration (markers on the chart) in comparison with (a) reaction enthalpy calculated based on the oxide composition of the raw material, (b) reaction enthalpy calculated based on the phase composition of the raw material

To gain even deeper insight into the thermokinetics of the ilmenite decomposition reaction, the dependence of the average rate of temperature change on the concentration of sulfuric acid has been investigated. The obtained relationships are shown in Fig. 7 and Fig. 8 for Norwegian and Australian ilmenite, respectively. Both graphs reveal a very strong influence of sulfuric 


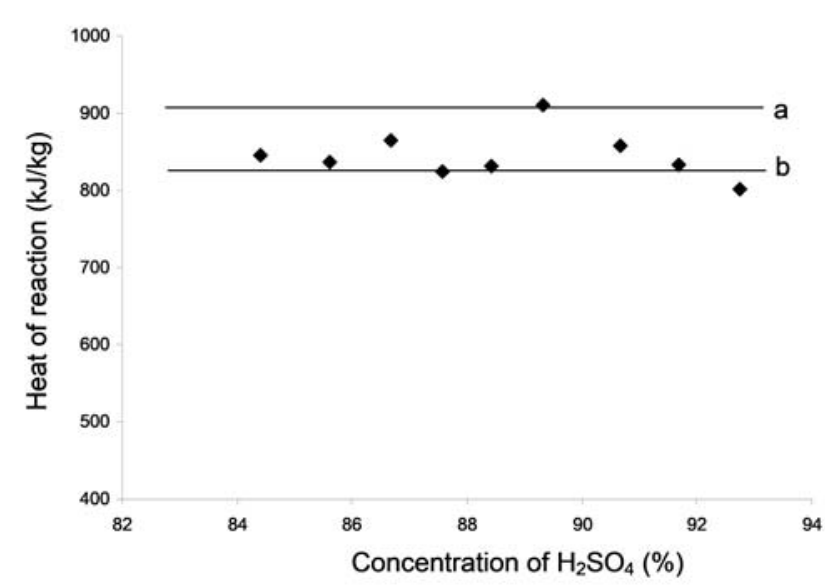

Figure 6. Dependence of the heat of the reaction of Australian ilmenite with sulfuric acid on the initial acid concentration (markers on the chart) in comparison with (a) reaction enthalpy calculated based on the oxide composition of the raw material, (b) reaction enthalpy calculated based on the phase composition of the raw material

acid concentration on the course of the reaction. The maximum values of $(\mathrm{dT} / \mathrm{dt})_{\mathrm{av}}$ occur at a sulfuric acid concentration of $95 \%$ for Norwegian ilmenite and $91 \%$ for Australian ilmenite. However, it can be seen that the concentration of sulfuric acid has a similar effect on the thermokinetics of the decomposition reactions of both ilmenites. The change of $(\mathrm{dT} / \mathrm{dt})_{\mathrm{av}}$ is $\sim 1.2 \mathrm{~K} / \mathrm{min}$ either for Norwegian and Australian ilmenite, for the same range of sulfuric acid concentration (84-91\%). As the concentration of sulfuric acid decreases, the value of (dT/ $\mathrm{dt})_{\mathrm{av}}$ also decreases and as a consequence a significant slowdown of the reaction can be observed. It can be assumed that mass transport processes (diffusion) are probably the main cause of this inhibition. However, the possible impact of diffusion on the experimentally observed phenomena will be addressed in detail in our next article.

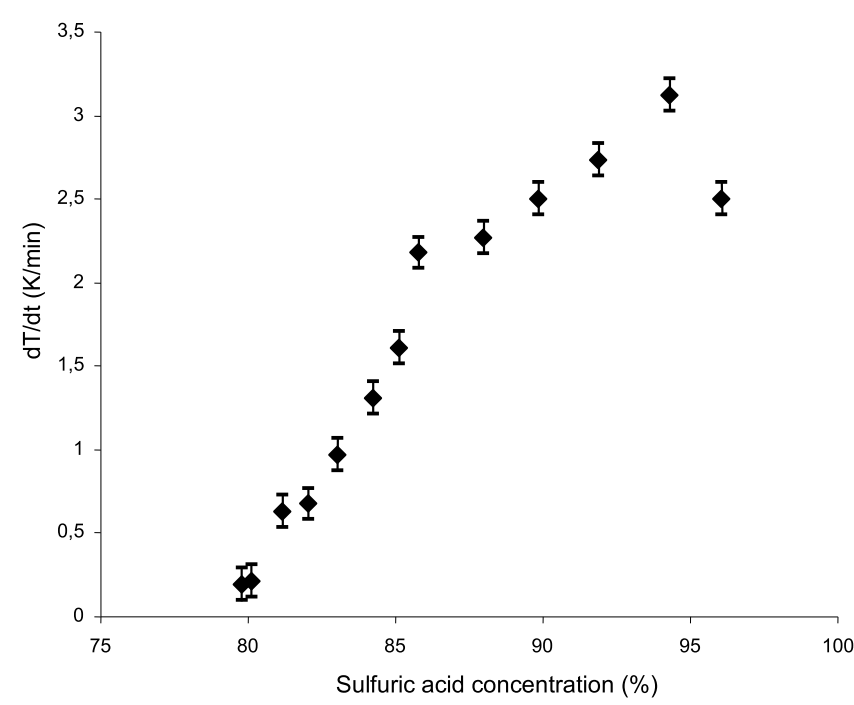

Figure 7. Dependence of the average rate of temperature changes during the reaction of Norwegian ilmenite with sulfuric acid on the initial concentration of sulfuric acid

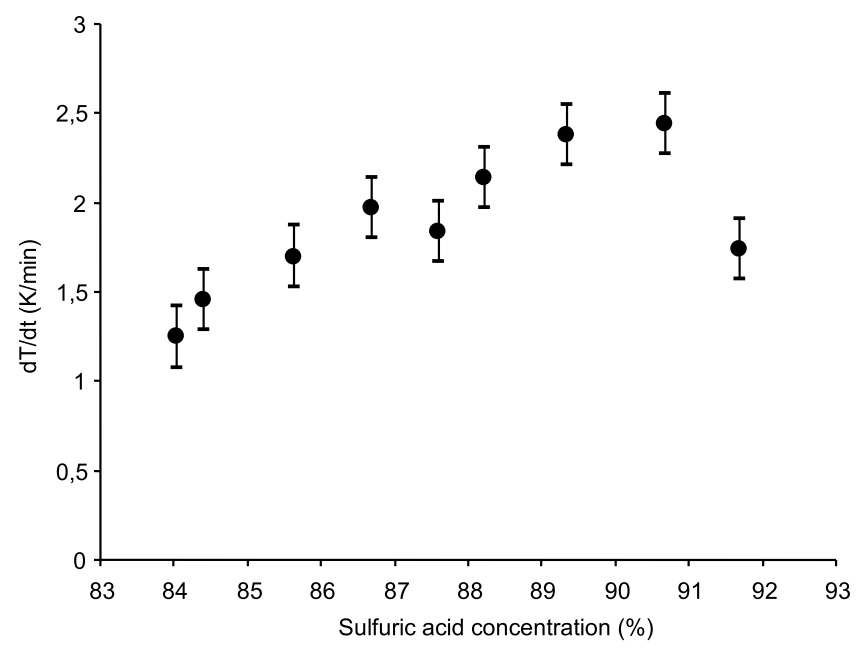

Figure 8. Dependence of the average rate of temperature changes during the reaction of Australian ilmenite with sulfuric acid on the initial concentration of sulfuric acid

\section{CONCLUSIONS}

As a result of the research on the reaction of Norwegian and Australian ilmenites with sulfuric acid, the enthalpies of these reactions were determined experimentally. The obtained values for Norwegian ilmenite (900-940 kJ/kg) and Australian ilmenite $(800-840 \mathrm{~kJ} / \mathrm{kg}$ ) showed good agreement with theoretical calculations, performed with the use of available thermodynamic data and based on the phase composition of the raw material.

It was found for both ilmenites that the heat of reaction does not depend on the initial concentration of sulfuric acid (in the concentration range from $83 \%$ to $93 \%$ ). On the other hand, a very strong influence of temperature and sulfuric acid concentration on the thermokinetics of the reaction was observed. At a sulfuric acid concentration below $80 \%$ and at temperatures below $333 \mathrm{~K}$ for Norwegian ilmenite and $353 \mathrm{~K}$ for Australian ilmenite a significant slowdown of the reaction was found. Increasing the temperature and concentration of sulfuric acid substantially increased the value of a crucial thermokinetic parameter of the decomposition process, namely the average rate of temperature change.

\section{LITERATURE CITED}

1. Blakey, R.R. \& Hall, J.E., Titanium Dioxide, in Pigment Handbook (P.A. Lewis, Ed.), Wiley, NY, 1987.

2. Winkler, J. (2003). Titanium Dioxide, Vincentz Network, Hannover.

3. Gázquez, M.J., Bolívar, J.P., García-Tenorio, R. \& Vaca, F., (2009). Physicochemical characterization of raw materials and co-products from the titanium dioxide industry, J. Hazard. Mater., 166, 1429-1440. DOI: 10.1016/j.jhazmat.2008.12.067.

4. Mantero, J., Gázquez, M.J., Bolívar, J.P., García-Tenorio, R. \& Vaca, F. (2013). Radioactive characterization of the main materials involved in the titanium dioxide production process and their environmental radiological impact. J. Environ. Radioact. 120, 26-32. DOI: 10.1016/j.jenvrad.2013.01.002.

5. Han, G., Wen, S., Wang, H. \& Feng, Q. (2020). Interaction mechanism of tannic acid with pyrite surfaces and its response to flotation separation of chalcopyrite from pyrite in a low-alkaline medium. J. Mater. Res. Technol., 9, 4421-4430. DOI: 10.1016/j.jmrt.2020.02.067. 
6. Zhang, Q., Wen, S., Feng, Q. \& Liu, J. (2021). Surface modification of azurite with lead ions and its effects on the adsorption of sulfide ions and xanthate species. Appl. Surf. Sci. 543, 148795. DOI: 10.1016/j.apsusc.2020.148795.

7. Dubenko, A.V., Nikolenko, M.V., Aksenenko, E.V., Kostyniuk, A. \& Likozar, B. (2020). Mechanism, Thermodynamics and Kinetics of Rutile Leaching Process by Sulfuric Acid Reactions. Processes 8, 640. DOI: 10.3390/pr8060640.

8. Dubenko, A.V., Nikolenko, M.V., Kostyniuk, A. \& Likozar, B. (2020). Sulfuric Acid Leaching of Altered Ilmenite Using Thermal. Mechanical and Chemical Activation. Minerals 10, 538. DOI :10.3390/min10060538.

9. Liang, B., Li, C., Zhang, C. \& Zhang, Y. (2005). Leaching kinetics of Panzhihua ilmenite in sulfuric acid. Hydrometallurgy 76, 173-179. DOI: 10.1016/j.hydromet.2004.10.006.

10. Johnson, R.W., Audy, S.W. \& Unwin, S.D. (2003). Essential Practices for Managing Chemical Reactivity Hazards, New York, AIChE.

11. Bretherick's Handbook of Reactive Chemical Hazards (P.G. Urben, Ed.), Academic Press, Amsterdam, 2006.

12. Zheng, Y., Zhang, C. \& Liu, H. (2020). The determination of isobaric heat capacities of liquid by the new flow calorimeter. Thermoch. Acta 690, 178644. DOI: 10.1016/j.tca.2020.178644.

13. Ding, J., Yu, L., Wang, J., Xu, Q. \& Ye, S. (2019). A symmetric dual-channel accelerating rate calorimeter with the varying thermal inertia consideration. Thermoch. Acta 678, 178304. DOI:/10.1016/j.tca.2019.178304.

14. Hany, C., Lebrun, H., Pradere, C., Toutain, J. \& Batsale, J.Ch. (2010). Thermal analysis of chemical reaction with a continuous microfluidic calorimeter. Chem. Engin. J. 160, 814-822. DOI: 10.1016/j.cej.2010.02.048.

15. Duh, Y.S., Hsu, C.C., Kao, C.S. \& Yu, S.W. (1996). Applications of reaction calorimetry in reaction kinetics and thermal hazard evaluation. Thermoch. Acta, 285, 67-9.

16. Ortín, J., Torra, V. \& Tachoire, H. (1987). Thermal power measurements in a differential-heat-conduction-scanning calorimeter at low temperature-scanning rates. Thermoch. Acta 121, 333-342. DOI: 10.1016/0040-6031(87)80183-1.

17. Leung, J.C., Fauske, H.K. \& Fisher, H.G. (1986). Thermal runaway reactions in a low thermal inertia apparatus. Thermoch. Acta 104, 13-29. DOI: 10.1016/0040-6031(86)85180-2.

18. Jabłoński, M. \& Tylutka, S. (2016). The influence of initial concentration of sulfuric acid on the degree of leaching of the main elements of ilmenite raw materials. J. Thermal Anal. Calorim. 124, 355-361. DOI: 10.1007/s10973-015-5114-y.

19. Przepiera, A., Jabłoński, M. \& Wiśniewski, M. (1993). Study of kinetics of reaction of titanium raw materials with sulphuric acid. J. Thermal Anal. 40, 1341-1345. DOI: 10.1007/ BF02546898.

20. Jabłoński, M. (2009). Influence of particle size distribution on thermokinetics of ilmenite with sulphuric acid reaction. J. Thermal Anal. Calorim. 96, 971-977. DOI: 10.1007/ s10973-009-0048-x.

21. Jabłoński, M., Ławniczak-Jabłońska, K. \& Klepka, M.T. (2012). Investigation of phase composition of ilmenites and influence of this parameter on thermokinetics of reaction with sulphuric acid. J. Thermal Anal. Calorim. 109, 1379-1385. DOI: 10.1007/s10973-011-2136-y.

22. Parapari, P.S., Irannajad, M. \& Mehdilo, A. (2016). Modification of ilmenite surface properties by superficial dissolution method. Miner. Engin., 92, 160-167. DOI: 10.1016/j. mineng.2016.03.016.

23. Jabłoński, M. (2010). Investigation of thermal power of reaction of titanium slag with sulphuric acid. Central Europ. J. Chem. 8(1), 149-154. DOI: 10.2478/s11532-009-0127-7.

24. Jabłoński, M. (2008). Investigation of reaction products of sulphuric acid with ilmenite, J.Thermal Anal. Calorim., 93, 717-720. DOI: 10.1007/s10973-008-9134-8.

25. Dobrovolski, I.P. (1988). The chemistry and technology of the oxide compounds of titanium, Sverdlovsk: UrO AN SSSR.

26. Wagman, D.D., Evans, W.H., Parker, V.B., Schumm, R.H., Halow, I., Bailey, S.M., Churney, K.L. \& Nuttall, R.L. (1982. The NBS Tables of Chemical Thermodynamic Properties. J. Phys. Chem. Ref. Data 11, Suppl. 2.

27. Barin, I. \& Knacke, O. (1973). Thermochemical properties of inorganic substances, Springer-Verlag Berlin Heildelberg New York.

28. Carl, L. (2009). Yaws' Handbook of Thermodynamic Properties for Hydrocarbons and Chemicals, Publisher Knovel, Electronic ISBN 978-1-60119-797-9.

29. Ginsberg, T., Modigell, M. \& Wilsmann, W. (2011). Thermochemical characterization of the calcination process step in the sulphate method for production of titanium dioxide, Chemical Engineering Research and Design, 89, 990-994. DOI: 10.1016/j.cherd.2010.11.006. 